\section{Radiocarbon dating of the Theran eruption}

\author{
Malcolm H. Wiener, Jason W. Earle \\ The Institute for Aegean Prehistory, \\ Greenwich, CT, USA
}

\begin{abstract}
Radiocarbon dates from material found in the Theran Volcanic Destruction Level are frequently said to require an earlier date for the event than the date range provided by the traditional chronology based on Near Eastern and Egyptian texts, archaeoastronomy, datable deposits of pumice from the eruption and numerous archaeological interconnections between Egypt, Cyprus and the Aegean. This paper considers a number of problems inherent in the proposed ${ }^{14} \mathrm{C}$ dating.
\end{abstract}

\section{Introduction}

This paper seeks to improve communication between radiocarbon specialists, archaeologists, ancient historians, dendrochronologists and mineralogists concerned with chronology. The achievements, limitations and problem areas of each discipline must be clearly communicated. We focus on the dating of the Bronze Age eruption of Thera (Figure 1) because the continuing controversy concerning the date illustrates clearly the major problems of archaeological radiocarbon dating and the lack of adequate communication between disciplines Furthermore, determining the date is important to our understanding of the interconnections between civilisations of the second millennium BC Eastern Mediterranean and of the development of Aegean societies. The massive eruption destroyed all sites on the island of Thera, a principal node on Aegean trade networks, and had a profound impact on the Minoan civilisation centered on Crete. The attempted dating of shortlived samples from the Volcanic Destruction Level at the harbour town of Akrotiri on the south coast of Thera benefits from the fact that there can be no doubt as to the archaeological context of the samples. Certain proposed radiocarbon dates of material from the Volcanic Destruction Level would place the eruption in the $17^{\text {th }}$ century $\mathrm{BC}$, or slightly thereafter, a result incompatible with the traditional historical/archaeological date c. 1525-1500 BC. The traditional chronology is based on Egyptian and Near Eastern textual/historical and astronomical records and numerous archaeological interconnections, now buttressed by analyses of pumice from the Theran eruption found in con- nection with Egyptian New Kingdom material. The oscillation of the calibration curve in the relevant period with peaks at c. 1615 and 1530 $\mathrm{BC}$ complicates the effort to date the eruption of the Theran volcano by radiocarbon measurements alone (Wiener, 1998, 2001, 2003a, 2003b, 2006, 2007, 2009a, 2009b, 2009c; Manning et al., 2009; Friedrich et al., 2009; Steinhauser et al., 2010).

\section{Problems of radiocarbon measurement and calibration}

Inter-laboratory variation in measurements of ${ }^{14} \mathrm{C}$ in divided samples, while recently significantly reduced in general, continues to exist. Unresolved disparities in measurements of trees of known dendrochronological date occur among logs from the same site (e.g., Gordion in Turkey for the years 1580, 1570 and $1560 \mathrm{BC}$ ); within measurements from trees in the same geographic area (e.g., two forests near the Rhine River at $1550 \mathrm{BC}$ ); and between the trees from Germany which form the backbone of the calibration curve and the trees from Gordion in a number of periods (e.g., c. 1325 and $1225 \mathrm{BC}$, 1080-990 BC, and especially between 850 and $750 \mathrm{BC}$, when the average offset is $28.8 \pm 26.3$ radiocarbon years) (Kromer et al., 2010). When radiocarbon measurements of trees of the same known date differ markedly, either at least one of the measurements is erroneous, whether because of differences in pretreatment or for some other reason, or the difference is deemed acceptable in light of the nature of the enterprise, in which case the result is of limited relevance to questions requiring narrow ranges to resolve, as in the case of the Theran measurements described below.

Intra-year seasonal variation in the production of ${ }^{14} \mathrm{C}$ also affects radiocarbon measurements. The difference between the summer high and winter low today generally ranges between eight and thirty-two radiocarbon years, and may exceed this range. In Egypt, where the growing season of seeds is principally in January-February in contrast to the May-June growing season of the Northern European oaks of the calibration curve, radiocarbon measurements of seeds of known date collected between AD 1700 and 1900 disclosed an offset of $19.5 \pm 5$ calibrated years earlier than calibration curve dates for this period (Dee, 2010). On Thera, the growing season of seeds is earlier than the calibration curve trees by only a matter of weeks, but the difference is still of potential relevance with respect to a claimed precision of \pm 7.5 radiocarbon years for the mean error of 28 measurements of 16 seeds and a twig from the destruction level, where a mean error range of \pm 20 would cause an overlap with the more recent peak of the
Correspondence: Malcolm H. Wiener, The Institute for Aegean Prehistory, 66 Vista Dr., Greenwich, CT 06830, USA.

Tel. +1.203.862.9334 - Fax: +1.203.625.0782.

E-mail: mhwiener@villacandia.com

Key words: radiocarbon dating, chronology, Theran eruption.

Acknowledgments: we are grateful to the organisers of the conference for the invitaition to participate, to the unnamed reviewer for many helpful comments, and to Jayne Warner, Erin Hayes and Rebecca Hahn for research and editorial assistance.

Citation: Wiener MH, Earle JW, 2014. Radiocarbon dating of the Theran eruption. In: RH Tykot (ed.), Proceedings of the $38^{\text {th }}$ International Symposium on Archaeometry - May $10^{\text {th }}$ - $14^{\text {th }} 2010$, Tampa, Florida. Open Journal of Archaeometry 2:5265.

Presented at the $38^{\text {th }}$ International Symposium on Archaeometry - May $10^{\text {th }}-14^{\text {th }} 2010$, Tampa, Florida.

This work is licensed under a Creative Commons Attribution 3.0 License (by-nc 3.0).

(C)Copyright M.H. Wiener and J.W. Earle, 2014 Licensee PAGEPress, Italy

Open Journal of Archaeometry 2014; 2:5265

calibration curve at 1530-25 BC. Further, seasonal variation prior to the impact of industrialisation on the atmosphere may have been greater (Keenan, 2004; Housley et al., 1999; Levin et al., 1992; Levin and Hesshaimer, 2000). In addition, calibration of radiocarbon measurements of seeds (with brief growing seasons within a single year) using decadal tree segments (with years of greatly varying ring thickness) creates an area of uncertainty. In a study published in Radiocarbon in 1998 the uncertainty was estimated to be in the range of five to eight radiocarbon years (Stuiver et al., 1998). The same study estimated the uncertainty resulting from the interaction of the 11-year sunspot cycle with the decadal calibration curve at a standard deviation of eight ${ }^{14} \mathrm{C}$ years. Accordingly the narrowness of the mean of the error range stated above would be suspect even apart from the likely and potentially more significant impact of the $\mathrm{CO}_{2}$ reservoir effects described below.

\section{Reservoir effects}

Reservoir effects of various kinds which add ${ }^{14} \mathrm{C}$-deficient carbon from sources in the earth or water to the ${ }^{14} \mathrm{C}$ content of the atmosphere present major problems with regard to Aegean radiocarbon measurements. Periodic upwelling of 
deep seawater releases ${ }^{14} \mathrm{C}$-deficient carbon into the atmosphere where it may be absorbed by plants, thus skewing measurements from coastal sites toward older dates (Rapp and Hill, 2006). Several studies suggest the possibility of upwelling of ${ }^{14} \mathrm{C}$-deficient carbon from the Aegean, either via the periodic exchange of water with the Black Sea which is rich in ${ }^{14} \mathrm{C}$ deficient carbon (Keenan, 2002), or the release of ${ }^{14} \mathrm{C}$-deficient carbon from underwater volcanic vents, one of which is located $7 \mathrm{~km}$ north-northeast of Thera (Carey et al., 2013; for vents near Melos see Pain, 1999). The critical sources of ${ }^{14} \mathrm{C}$-deficient carbon in various areas include volcanic and non-volcanic gas vents, geothermal fields, and general soil degassing (Frezzotti $e t$ al., 2009). In Italy the area of terrestrial $\mathrm{CO}_{2}$ emissions stretches from Tuscany to Sicily, and from the Tyrrhenian Sea to the Apennines (Frezzotti et al., 2009). Similar emissions have been observed in areas of southern Italy, and on the volcanic island of Stromboli (Rogie, 1996; Chiodini et al., 1999, 2004; Rogie et al., 2000; Cardellini et al., 2003; Gambardella et al., 2004; Minissale et al., 1997; Carapezza et al., 2009; Brandherm, 2008; Nijboer and van der Plicht, 2008). Reported radiocarbon dates from Italian sites whose historical contexts are clear are often 70-250 years too early (Turfa, 2006). A similar phenomenon is reported with regard to Iceland, where volcanic/geothermal effects are thought to be the cause of radiocarbon dates 100-200 years earlier than presumed historical dates for the earliest European occupation levels (Sveinbjörnsdóttir and Heinemeier, 2011). At Sulphur Banks on Hawaii, three living tree ferns and one Ohia leaf growing 1 to 5 miles from a volcanic vent gave radiocarbon ages between 81 and 303 years (Chatters et al., 1969). In addition, groundwater that has been in contact with soil degassing or with limestone, a notorious source of ${ }^{14} \mathrm{C}$-deficient carbon, if absorbed by plants or consumed by living creatures, sometimes results in measurements which provide dates that are older than true dates (Mörner and Etiope, 2002; Fischer and Heinemeier, 2003; Rapp and Hill, 2006). While in a few reported cases measurements of contemporary plants growing immediately adjacent to a current point source of volcanic carbon have produced radiocarbon ages far too early (Bruns et al., 1980; Pasquier-Cardin et al., 1999), many measurements of short-lived samples from areas of gas emissions have provided dates in the range of 70-300 years earlier than the dates appropriate for the historical contexts of the samples.

\section{Statistical and calibration issues}

The combination and calibration of radio- carbon measurements, based on Gaussian and Bayesian statistics and conventions employed in the various calibration programs, pose many issues. AMS laboratories employ different methods of analyses, some unpublished. The method chosen can have a significant impact on the reported findings and conclusions. The commonly used standard error of the mean can be too small or too large by a factor of two, but on average is too small; moreover, radiocarbon intercomparisons assume a Gaussian bellcurve distribution of the results even though this is known not to be the case (Palonen et al., 2010). Boaretto et al. (2005) noted that ${ }^{14} \mathrm{C}$ measurements generally do not conform to the ideal standard distribution; rather the actual distribution under extensive replication is wider than the quoted errors, even after the exclusion of outliers. The quoted error denotes at best the variability within the same measurement run. Sometimes even the meaning of basic terms differs between laboratories. The OxCal, Calib and Demokritos Laboratory (Athens) programs differ, for example, in their use of probability. In the 0xCal program $80 \%$ probability means $80 \%$ of 100 , whereas in the Calib program it means $80 \%$ out of the twosigma standard deviation of $95.4 \%$, and the Demokritos program is unique, generally giving broader ranges (in our view appropriately so), but is susceptible of reaching results different from those of the other programs from the same data (Y. Maniatis, personal communication of 6 April 2010). Other differences exist as well. Another radiocarbon laboratory, Beta Analytic, employs the Pretoria Calibration Procedure which smoothes actual calibration curve measurements employing a spline (Talma and Vogel, 1993), whereas INTCAL04 and INTCAL09 utilise a Random Walk Model, but smooth the results by incorporating data from earlier and later decadal measurements.

Most importantly, all calibration programs narrow stated error ranges in direct response to the number of measurements included - the more measurements, the narrower the range without great regard to the consistency or inconsistency (even when substantial) of the measurements themselves, provided the measurements meet the chi-square test. Note that the 0xCal 4.1 programme, described in Ramsey (2009), deals with disparate measurements of samples from the same event horizon by giving significantly less weight to measurements on the boundaries as distinguished from those in the center, while acknowledging that the definition of outliers is somewhat arbitrary. Differing statistical treatment of outliers can produce significantly different dates, as illustrated in Ramsey (2009). The chisquare test itself, however, is logically dependent on the existence of Ward and Wilson Case I (Ward and Wilson, 1978) which specifies that the method is appropriate only when the meas- urements are known to represent the same event (e.g., measurements from the bones of a single corpse). The test has often been utilised when the evidence is ambiguous in this regard, however. For example, the Ward and Wilson Case I analysis has been applied to seeds from the Volcanic Destruction Level at Thera (Manning et al., 2006). Here, however, it is not clear whether some of the seeds were collected before the preliminary eruption which caused the populace to flee, or between that point and the final phase, during which some returned to try to rebuild or rescue items of value, nor whether all the seeds measured came from the same field or fields of varying distance from preexisting point, fault, or field of gas emissions capable of producing distorting reservoir effects. In any event, the Theran measurements produced radiocarbon age ranges whose central dates were as much as 350 years apart; dates for one species (grass pea) 215 years apart, and dates for another (barley) 97 years apart (Manning et al., 2006). However, because 28 measurements (some of which preceded modern pretreatment and high-precision dating methods) were available, the stated mean error range was only \pm 7.5 radiocarbon years. In a recent issue of Radiocarbon, Russell et al. (2011) in their discussion of errors associated with ${ }^{14} \mathrm{C}$ analysis procedures highlight inappropriate errors placed on the age measurements, observing that /tJhis has to be a realistic estimate of the error and should not be based solely on counting statistics. Even apart from the likelihood of at least some reservoir effects on measurements of material from Thera, the narrowness of the stated error range reflects the statistical conventions employed rather than the underlying reality of the volcanic nature of Thera and the surrounding sea. The claimed precision is essential, however, to the proposition that radiocarbon dates strongly support Manning's proposed Aegean Long Chronology because, as Manning (2005) has previously noted, any age in the $3320 \mathrm{~s}$ BP is potentially compatible with historical dating in light of the oscillating calibration curve (Figure 2). With an error band of \pm 25 rather than \pm 7.5 , the stated radiocarbon age of 3344.9 BP would be potentially compatible with a date for the eruption of c. $1525 \mathrm{BC}$, even without any correction for any potential seasonal/regional offset or more significantly, for the reservoir effects of ${ }^{14} \mathrm{C}$-deficient carbon (Wiener, 2009a; 2009b).

Ramsey has noted (personal communication of 30 December 2009) that there are two potential methods within the $0 x \mathrm{xal}$ program of addressing the sources of uncertainty noted. The first is to insert a range which the investigator $-e . g$., the archaeologist submitting the samples - regards as a minimal acceptable error range, based on her/his understanding of the circumstances concerning the samples 
submitted for radiocarbon measurement. In practice this is never done, inasmuch as archaeologists seldom understand the complex statistical issues involved. The second method is to introduce an asymmetric adjustment to the error range toward older dates to allow for estimated local reservoir (and/or regional/seasonal) effects. Such putative effects are also impossible to quantify, however. Considerable sophistication in relevant sciences and statistics, as well as a degree of courage, would be required of any archaeologist choosing such a course. It would also be possible to employ the earliest plausible date indicated by the wellfounded historical date range for the Theran eruption as a Bayesian boundary, but it is precisely this historical dating which the radiocarbon determinations in question are said to challenge.

A recent attempt by Friedrich et al. (2006) to date a branch from an olive tree found in the volcanic tephra on Thera c. $7 \mathrm{~km}$ from

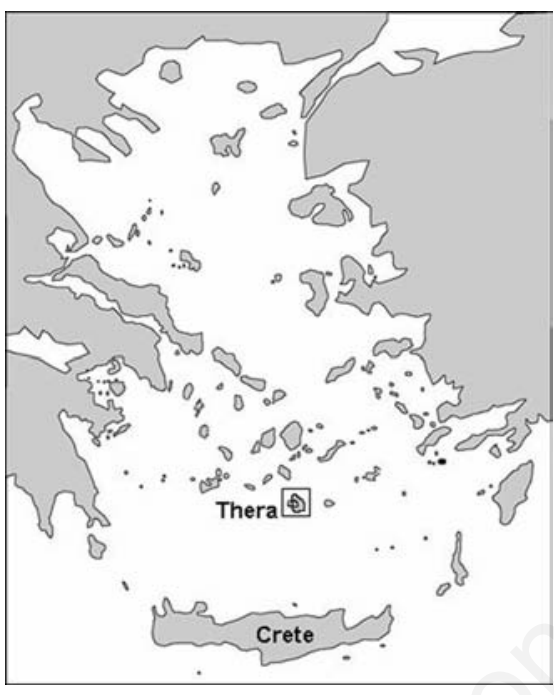

Figure 1. Location of Thera, Greece.

Figure 2. Oscillating calibration curve of

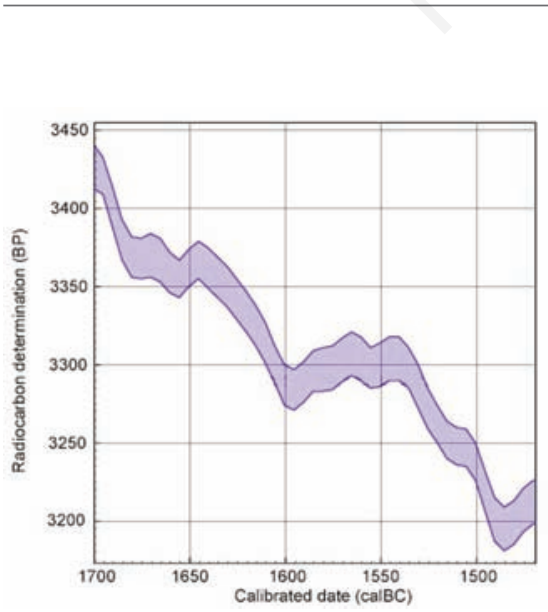

radiocarbon dates.
Akrotiri presents its own problems. First, there is no way of knowing whether the olive branch was living at the time of the eruption. Aegean olive trees are often covered in long-dead branches since their owners hesitate to remove them for fear of damaging the tree $(0$. Rackham, personal communication of 11 May 2008; H. Blitzer, personal communication of 23 July 2008). Second, the claim that the investigators have been able via X-ray tomography to count year rings on the branch is severely challenged by reports from dendrological laboratories that rings of olive trees are impossible to count with any confidence. In blind tests no two laboratories could agree on the number of rings on olive tree branches recently collected on Thera. Moreover, olive trees do not form anything approaching annual rings even if agreement could be achieved on the number (Humbel, 2009; Cherubini et al., 2003), which vitiates also the wigglematch to the calibration curve claimed by Friedrich et al. (2006). The claim by Friedrich et al. (2006) that they have allowed for uncertainties in the ring count of up to $25 \%$ in this regard seems disingenuous, inasmuch as it refers to an allowance of \pm 3 rings in an asserted 12-ring segment, given that no such precision is achievable, even apart from the fact that olive trees do not make annual rings. The fact that the 4 segments of the branch studied by Friedrich et al. (2006) gave radiocarbon measurements which descended in order is also not germane, since this would be true in any event $-e . g$., if the 4 segments each contained a $1 \%$ reservoir of ${ }^{14} \mathrm{C}$-deficient carbon resulting in measurements c. 80 years too old, the measurements of the four segments would still descend in order.

\section{Other archaeometric evidence for the dating of the eruption}

Four hundred and fifteen samples of pumice and tephra from the Minoan eruption of Thera have been found a minimum of 15 sites in Egypt, the Levant, Cyprus and the Aegean, all of them from New Kingdom contexts, whereas the 27 examples of pumice from earlier contexts all come from nonTheran eruptions. The investigators note that if the Aegean Long Chronology were correct, it would indeed be most peculiar a phenomenon that pumice from the Minoan Santorini eruption were abundantly available along the shores of the Eastern Mediterranean, yet for some reason had been left unnoticed and unused by the local inhabitants for 100-150 years (Steinhauser et al., 2010), to which we may add that it would also be peculiar if so valuable a substance with 14 known uses in antiquity, and especially useful in metallurgy (Wiener and Allen, 1998), was ignored for a century before traders brought it to all the Egyptian, Levantine, Cypriot and Aegean sites where it is attested, as suggested by Manning (1999) (cf. also Bietak, 2004). At one of the sites, Tell el 'Ajjul near Gaza, Theran pumice, Egyptian New Kingdom pottery, and Cypriot White Slip I pottery similar to a bowl recovered from the Theran Volcanic Destruction Level are accompanied by four radiocarbon dates from seeds which center on c. $1525 \mathrm{BC}$., the historically and archaeologically appropriate date for the eruption, while only touching the Aegean Long Chronology eruption date range at the limit of the two-sigma probability distribution (Figure 3 ).

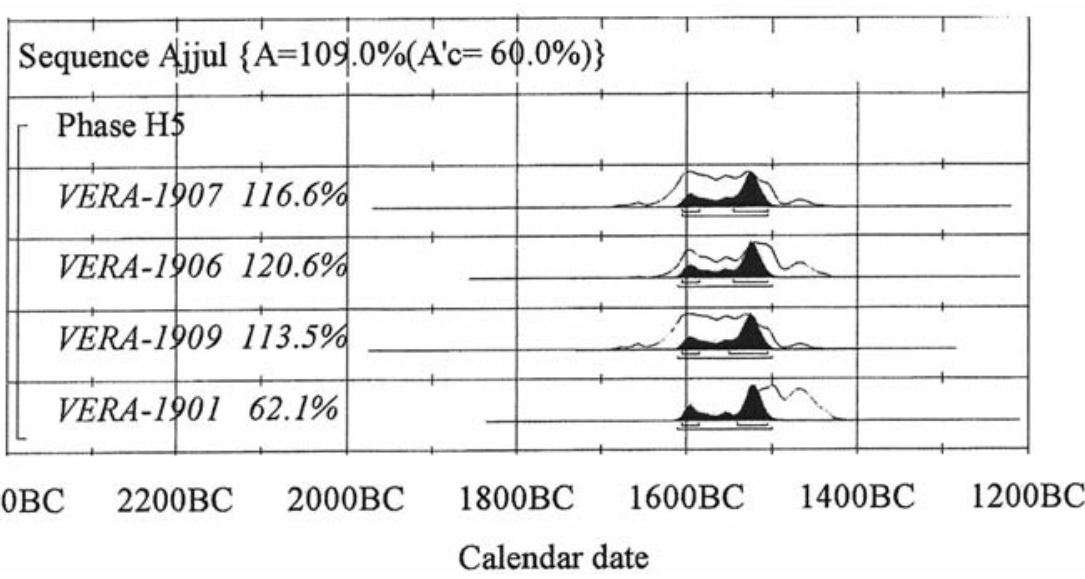

Figure 3. Radiocarbon dates from Stratum H5 at Tell el 'Ajjul. 


\section{Conclusions}

Radiocarbon determinations for the date of the Theran eruption may center somewhat earlier than the well-established historical date range due to: i) factors specific to the area of the eruption; and ii) uncertainties inherent in the process of calibration and the assumptions on which the estimates of probability and precision are based. Specific factors include i) the oscillating nature of the calibration curve between c. 1615 and $1525 \mathrm{BC}$; ii) the particular reservoir effects likely present in measurements of samples from volcanic Thera; and iii) seasonal/regional differences between Aegean seeds/trees and northern oaks in cases where an asserted error range of less than $\pm 20{ }^{14} \mathrm{C}$ years is critical to the conclusion stated. Inherent problems include i) the irregular character of the calibration curve and the intrinsic uncertainties of calibration in general; ii) the statistical paradigms employed, which narrow error bands in response to the number of measurements made, however disparate, provided they meet the chi-square test, the appropriateness of which rests on the assumption that the requirements of Ward and Wilson Case I have been met; and iii) the general failure to convey to archaeologists who submit samples for dating that the meaning of the term probability in statistical usage differs from the meaning in general usage, where the term implies that all sources of uncertainty and all contradictory evidence have been considered. (The terms likelihood and confidence display similar differences between statistical and standard English meaning). Archaeologists submitting samples typically are unaware of the existence of such issues, notwithstanding that articles dealing separately with many of the problems discussed have appeared over the years in radiocarbon, statistical or general archaeometric journals. Radiocarbon laboratories accordingly have a professional obligation to inform their clients clearly of the uncertainties and limitations of radiocarbon dating, both with regard to the particular samples submitted and in general. The duty is magnified when proposing a date range for an event as important as the date of the Theran eruption, which affects the chronology and history of the entire Eastern Mediterranean world.

\section{References}

Bietak M, 2004. Review of A test of time (1999). Biblioteca Orientalis 61:199-222.

Boaretto E, Jull AJT, Gilboa A, Sharon I, 2005. Dating the Iron Age I/II transition in Israel: first intercomparison results. Radiocarbon 47:39-55.
Brandherm D, 2008. Greek and Phoenician potsherds between East and West: a chronological dilemma? In: D. Brandherm, M. Trachsel (eds.) A new dawn for the Dark Age? Shifting paradigms in Mediterranean Iron Age chronology. Proceedings of the XV UISPP world congress (Lisbon 4-9 September 2006). Archaeopress, Oxford, pp. 149-74.

Bruns M, Levin I, Münnich KO, Hubberten HW, Fillipakis S, 1980. Regional sources of volcanic carbon dioxide and their influence on 14C content of present-day plant material. Radiocarbon 22:532-6.

Carapezza ML, Ricci T, Ranaldi M, Tarchini L, 2009. Active degassing structures of Stromboli and variations in diffuse $\mathrm{CO} 2$ output related to the volcanic activity. J Volcanol Geoth Res 182:231-45.

Cardellini C, Chiodini G, Frondini F, Giaquinto S, Caliro S, Parello F, 2003. Input of deeply derived carbon dioxide in southern Apennine regional aquifers (Italy). J Geophys Res 105:8423-34.

Carey S, Nomiku P, Croff Bell K, Lupton J, Roman C, Stathopoulou E, Bejelou K, Ballard R, 2013. Co2 degassing from hydrotermal vents at Kolumbo submarine volcano, Greece, and the accumulation of acidic crater water. Geology 41:1035-8.

Chatters RM, Crosby JW, III, Engstrand LG, 1969. Fumarole gaseous emanations: their influence on carbon-14 dates. Washington State University College of Engineering Publ., Washington, DC, USA.

Cherubini P, Gartner BL, Tognetti R, Bräker OU, Schoch W, Innes JL, 2003. Identification, measurement and interpretation of tree rings in woody species from Mediterranean climates. Biol Rev 78:11948.

Chiodini G, Cardellini C, Amato A, Boschi E, Caliro S, Frondini F, Ventura G, 2004. Carbon dioxide earth degassing and seismogenesis in central and southern Italy. Geophys Res Lett 31:L07615.

Chiodini G, Frondini F, Kerrick DM, Rogie J, Parello F, Peruzzi L, Zanzari AR, 1999. Quantification of deep CO2 fluxes from central Italy. Examples of carbon balance for regional aquifers and of soil diffuse degassing. Chem Geol 159:205-22.

Dee M, 2010. Investigating the accuracy of radiocarbon dating in Egypt: checks with samples of known age. In: A.J. Shortland, C. Bronk Ramsey (eds.) Radiocarbon and the Chronologies of Ancient Egypt. Oxbow Book ed., Oxford, pp. 53-64.

Fischer A, Heinemeier J, 2003. Freshwater reservoir effect in $14 \mathrm{C}$ dates of food residue on pottery. Radiocarbon 45:449-66.

Frezzotti ML, Peccerillo A, Panza G, 2009. Carbonate metasomatism and CO2 lithosphere: asthenosphere degassing beneath the Western Mediterranean: an integrated model arising from petrological and geophysical data. Chem Geol 262:108-20.

Friedrich WL, Kromer B, Friedrich M, Heinemeier J, Pfeiffer T, Talamo S, 2006. Santorini eruption radiocarbon dated to 1627-1600 B.C. Science 312:548.

Friedrich WL, Kromer B, Friedrich M, Heinemeier J, Pfeiffer T, Talamo S, 2009. Santorini eruption radiocarbon dated to 1627-1600 B.C: further discussion. In: S.W. Manning, M.J. Bruce (eds.) Tree-rings, kings, and Old World archaeology and environment. Papers presented in honor of Peter Ian Kuniholm. 0xbow, Oxford, pp. 293-8.

Gambardella B, Cardellini C, Chiodini G, Frondini F, Marini L, Ottonello G, Zuccolini MV, 2004. Fluxes of deep CO2 in volcanic areas of central-southern Italy. J Volcanol Geoth Res 136:31-52.

Housley RA, Manning SW, Cadogan G, Jones RE, Hedges REM, 1999. Radiocarbon, calibration and the chronology of the Late Minoan IB Phase. J Archaeol Sci 26:15971.

Humbel T, 2009. [Jahrringidentifikation von Olivenbäumen auf Santorin zur Bestätigung von dendrochronologischen Datierungen der minoischen Eruption (Masterarbeit)]. [Book in German]. University of Zürich ed., Zürich.

Keenan DJ, 2002. Why early-historical radiocarbon dates downwind from the Mediterranean are too early. Radiocarbon 44:225-37.

Keenan DJ, 2004. Radiocarbon dates from Iron Age Gordion are confounded. Ancient West \& East 3:100-3.

Kromer B, Manning SW, Friedrich M, Talamo S, Trano N, 2010. 14C Calibration in the 2nd and 1st Millennia BC: Eastern Mediterranean Radiocarbon Comparison Project (EMRCP). Radiocarbon 52:875-86.

Levin I, Bösinger R, Bonani G, Francey RJ, Kromer B, Münnich K0, Suter M, Trivett NBA, Wölfli W, 1992. Radiocarbon in atmospheric carbon dioxide and methane: global distribution and trends. In: R.E. Taylor, A. Long, R.S. Kra (eds.) Radiocarbon after four decades: an interdisciplinary perspective. Springer, Berlin, pp. 50318.

Levin I, Hesshaimer V, 2000. Radiocarbon: a unique tracer of global carbon cycle dynamics. Radiocarbon 42:69-80.

Manning SW, 1999. A test of time. Oxbow, Oxford.

Manning SW, 2005. Simulation and the Thera eruption: outlining what we do and do not know from radiocarbon. In: A. DakouriHild, S. Sherratt (eds.) Autochthon: papers presented to 0.T.P.K. Dickinson on the occasion of his retirement. Oxbow, Oxford, 
pp. 97-114.

Manning SW, Bronk Ramsey C, Kutschera W, Higham T, Kromer B, Steier P, Wild EM, 2006. Chronology for the Aegean Late Bronze Age 1700-1400 B.C. Science 312:565-9.

Manning SW, Bronk Ramsey C, Kutschera W, Higham T, Kromer B, Steier P, Wild EM, 2009. Dating the Santorini/Thera eruption by radiocarbon: further discussion (AD 2006-2007). In: S.W. Manning, M.J. Bruce (eds.) Tree-rings, kings, and Old World archaeology and environment. Papers presented in honor of Peter Ian Kuniholm. 0xbow, Oxford, pp. 299-316.

Minissale A, Magro G, Vaselli 0, Verrucchi C, Perticone I, 1997. Geochemistry of water and gas discharges from the Mt. Amiata silicic complex and surrounding areas (central Italy). J Volcanol Geoth Res 79:223-51.

Mörner N-A, Etiope G, 2002. Carbon degassing from the lithosphere. Global Planet Change 33:185-203.

Nijboer AJ, van der Plicht J, 2008. The Iron Age in the Mediterranean: recent radiocarbon research at the University of Groningen. In: D. Brandherm, M. Trachsel (eds.) A new dawn for the Dark Age? Shifting paradigms in Mediterranean Iron Age chronology. Proc. of the XV UISPP world congress (Lisbon 4-9 September 2006). Archaeopress, 0xford, pp. 103-18.

Pain S, 1999. [Vents de Milos]. [Article in French]. New Sci 103:38-41.

Palonen V, Tikkanen P, Keinonen J, 2010. Using car4ams, the Bayesian AMS data analysis code. Radiocarbon 52:948-52.

Pasquier-Cardin A, Allard P, Ferreira T, Hatte C, Coutinho R, Fontugne M, Jaudon M, 1999. Magma-derived CO2 emissions recorded in $14 \mathrm{C}$ and $13 \mathrm{C}$ content of plants growing in Furnas Caldera, Azores. J Volcanol Geoth Res 92:195-208.

Ramsey CB, 2009. Dealing with outliers and offsets in radiocarbon dating. Radiocarbon 51:1023-45.

Rapp GR, Hill CL, 2006. Geoarchaeology: the earth-science approach to archaeological interpretation. Yale University Press, New Haven.

Rogie JD, 1996. Lethal Italian carbon dioxide springs key to atmospheric CO2 levels. Available from: http://www.eesi.psu. edu/news_events/archives/Lethal.shtml

Rogie JD, Kerrick DM, Chiodini G, Frondini F, 2000. Flux measurements of nonvolcanic
C02 emission from some vents in central Italy. J Geophys Res 105:8435-45.

Russell N, Cook GT, Ascough PL, Scott EM, Dugmore AJ, 2011. Examining the inherent variability in R: new methods of presenting $R$ values and implications for MRE studies. Radiocarbon 53:277-88.

Steinhauser G, Sterba JH, Oren E, Foster M, Bichler M, 2010. Provenancing of archaeological pumice finds from North Sinai. Naturwissenschaften 97:403-10.

Stuiver M, Reimer PJ, Bard E, Warren Beck J, Burr GS, Hughen KA, Kromer B, McCormac G, van der Plicht J, Spurk M, 1998. INTCAL98 radiocarbon age calibration, 24,000-0 cal BP. Radiocarbon 40:104183.

Sveinbjörnsdóttir ÁE, Heinemeier J, 2011. The controversy of the settlement time of Iceland. Paper presented at Radiocarbon and Archaeology, 6th International Symposium; 2011 April 10-15, Pafos, Cyprus.

Talma AS, Vogel JC, 1993. A simplified approach to calibrating $14 \mathrm{C}$ dates. Radiocarbon 35:317-22.

Turfa JM, 2004. Review of 'Oriente e Occidente: metodi e discipline a confronto. Riflessioni sulla cronologia dell'età del ferro in Italia. Atti dell'incontro di studi, Roma, 2003 ottobre 30-31. Mediterranea, 1 (2004)'. Bryn Mawr Classical Review 2006.08.10. Available from: http://bmcr.brynmawr.edu/2006/2006-0810.html

Ward GK, Wilson SR, 1978. Procedures for comparing and combining radiocarbon age determinations: a critique. Archaeometry 20:19-31.

Wiener MH, 1998. The absolute chronology of Late Helladic IIIA2. In: M.S. Balmuth, T.H. Tykot (eds.) Sardinian and Aegean chronology: towards the resolution of relative and absolute dating in the Mediterranean. Proceedings of the International Colloquium 'Sardinian Stratigraphy and Mediterranean Chronology', Tufts University, Medford, MA, 1995 March 17-19. 0xbow, Oxford, pp. 309-19.

Wiener MH, 2001. The White Slip I of Tell elDab'a and Thera: critical challenge for the Aegean Long Chronology. In: V. Karageorghis (ed.) The White Slip ware of Late Bronze Age Cyprus. Proceedings of an International Conference Organized by the Anastasios G. Leventis Foundation, Nicosia in Honour of Malcolm Wiener,
Nicosia, 1998 October 29-30. Verlag der Österreichischen Akademie der Wissenschaften ed., Vienna, pp. 195-202.

Wiener MH, 2003a. The absolute chronology of Late Helladic IIIA2 revisited. Annual of the British School at Athens 98:239-50.

Wiener MH, 2003b. Time out: the current impasse in Bronze Age archaeological dating. In: K.P. Foster, R. Laffineur (eds.) METRON: measuring the Aegean Bronze Age. Proceedings of the 9th International Aegean Conference, New Haven, Yale University, 2002 April 18-21. Program in Aegean Scripts and Prehistory ed., Austin, TX, pp. 363-99.

Wiener MH, 2006a. Chronology going forward (with a query about 1525/4 B.C.). In: E. Czerny, I. Hein, H. Hunger, D. Melman, A. Schwab (eds.) Timelines. Studies in honour of Manfred Bietak. Vol. 3. Peeters ed., Leuven, pp. 317-28.

Wiener MH, 2006b. Egypt \& time. Egypt and the Levant 16:325-39.

Wiener MH, 2007. Times change: the current state of the debate in Old World chronology. In: M. Bietak, E. Czerny (eds.) The synchronisation of civilisations in the Eastern Mediterranean in the second millennium B.C. III. Proceedings of the SCIEM 20002nd EuroConference, Vienna, 2003 May 28-June 1. Verlag der Österreichischen Akademie der Wissenschaften ed., Vienna, pp. 25-47.

Wiener MH, 2009a. Cold fusion: the uneasy alliance of history and science. In: S.W. Manning, M.J. Bruce (eds.) Tree-rings, kings, and Old World archaeology and environment. Papers presented in honor of Peter Ian Kuniholm. 0xbow, Oxford, pp. 277-92.

Wiener MH, 2009b. Reply to the papers by Manning et al. and Friedrich et al. In: S.W. Manning, M.J. Bruce (eds.) Tree-rings, kings, and Old World archaeology and environment. Papers presented in honor of Peter Ian Kuniholm. Oxford: 0xbow, pp. 317-32.

Wiener MH, 2009c. The State of the debate about the date of the Theran eruption. In: Warburton D, ed Time's up: dating the Minoan eruption of Santorini. Acts of the Minoan Eruption Chronology Workshop, Sandbjerg (November 2007). Aarhus University Press, Aarhus, pp. 197-206.

Wiener MH, Allen JP, 1998. Separate lives: the Ahmose Tempest Stela and the Theran eruption. J Near Eastern Stud 57:1-28. 